\title{
TU/e EmonOWEN

\section{Design of an ion temperature diagnostic based on neutral beam scattering}

\section{Citation for published version (APA):}

Heesch, van, E. J. M., Hirose, A., Sarkissian, A., \& Skarsgard, H. M. (1986). Design of an ion temperature diagnostic based on neutral beam scattering. Review of Scientific Instruments, 57(8), 1792-1793. https://doi.org/10.1063/1.1139184

DOI:

10.1063/1.1139184

Document status and date:

Published: 01/01/1986

\section{Document Version:}

Publisher's PDF, also known as Version of Record (includes final page, issue and volume numbers)

\section{Please check the document version of this publication:}

- A submitted manuscript is the version of the article upon submission and before peer-review. There can be important differences between the submitted version and the official published version of record. People interested in the research are advised to contact the author for the final version of the publication, or visit the $\mathrm{DOI}$ to the publisher's website.

- The final author version and the galley proof are versions of the publication after peer review.

- The final published version features the final layout of the paper including the volume, issue and page numbers.

Link to publication

\section{General rights}

Copyright and moral rights for the publications made accessible in the public portal are retained by the authors and/or other copyright owners and it is a condition of accessing publications that users recognise and abide by the legal requirements associated with these rights.

- Users may download and print one copy of any publication from the public portal for the purpose of private study or research.

- You may not further distribute the material or use it for any profit-making activity or commercial gain

- You may freely distribute the URL identifying the publication in the public portal.

If the publication is distributed under the terms of Article 25fa of the Dutch Copyright Act, indicated by the "Taverne" license above, please follow below link for the End User Agreement:

www.tue.nl/taverne

Take down policy

If you believe that this document breaches copyright please contact us at:

openaccess@tue.nl

providing details and we will investigate your claim. 


\title{
Design of an ion temperature diagnostic based on neutral beam scattering
}

\author{
E. J. M. van Heesch, A. Hirose, A. Sarkissian, and H. M. Skarsgard
}

Plasma Physics Laboratory, Department of Physics, University of Saskatchewan, Saskatoon Saskatchewan, Canada $S 7 N$ OWO

(Presented on 10 March 1986)

\begin{abstract}
Small-angle neutral beam scattering will be used on the STOR-M tokamak to obtain space and time-resolved measurements of the ion temperature. Advantages of the technique and experimental considerations leading to the design are discussed. It is expected that a $20-30-\mathrm{keV}$ helium beam of $35-65-\mathrm{A} / \mathrm{m}^{2}$ current density together with a large area chevron channel-plate detector and automatic data handling will allow direct determination of ion temperatures at an accuracy of $10 \%$, a temporal resolution of $40 \mu \mathrm{s}$, and a spatial resolution better than $1 \mathrm{~cm}$.
\end{abstract}

\section{INTRODUCTION}

An analysis of the scattering method was given by Abramov et al. in 1970. 'The scattered spectrum is centered around a high energy $E_{0}$, just below the beam energy $E_{b}$. The width $\sigma$ of this spectrum is directly related to the ion temperature. Therefore, localized measurements of the ion temperature are relatively unaffected by attenuation of the particle flux, detection of background neutrals, and poorly known temperature and density profiles. These important advantages over passive and active charge exchange methods will allow the use of the scattering technique on future fusion devices with increased density and size.

The first experimental results, in which a tokamak plasma was probed with an $8-\mathrm{keV}$ He beam were reported by Aleksandrov ${ }^{2}$ and Berezovskii. ${ }^{3}$ In the present approach a $20-30-\mathrm{keV}$ beam will be used along with high counting performance and automatic data acquisition to facilitate the determination of temperature profiles.

The broadening of the initial narrow spectrum by the scattering process is expressed in the differential count rate $d \Gamma$ of particles in the energy interval $d E$ scattered at an angle $\theta$ into a solid angle $d \Omega$,

$$
\frac{1}{\sqrt{E}} \frac{d \Gamma}{d E d \Omega}=C_{0} \frac{1}{\sigma \sqrt{2 \pi}} \exp \left[-\frac{1}{2}\left(\frac{E-E_{0}}{\sigma}\right)^{2}\right] \text {, }
$$

where

$$
\begin{aligned}
& \sigma=\sin \theta \sqrt{2 \gamma E_{b} T_{i}}, \\
& E_{0}=\left[1-\gamma(\sin \theta)^{2}\right] E_{b}, \\
& C_{0}=\frac{1}{2}\left(2 \pi \epsilon_{0}\right)^{-2} Z_{b}^{2} Z_{p}^{2} e J S_{d} D_{b} n_{i}\left(\sin \theta \sqrt{E_{b}}\right)^{-5},
\end{aligned}
$$

and $J$ is the beam equivalent current density, $\gamma$ is the mass ratio of beam to plasma particles, $S_{d}$ is the detector active area, and $D_{b}$ is the beam diameter. For Eq. (1) to be valid it is required that $E_{b}>k T_{i}$.

A description of various experimental conditions to be chosen was given by Berezovskii. ${ }^{3}$ We will focus on the effects of a further broadening of the Gaussian distribution of Eq. (1) by the beam divergence and the source characteristics. Since the total count rate over the spectrum $\Gamma_{\text {tot }}=C_{0} \sqrt{E_{0}} d \Omega$, is proportional to $(\sin \theta)^{-5}, \theta$ has to be restricted to small values. Consequently, the length $l$ of the scattering volume (the intersecting region of the beam and line of sight) becomes quite large and a precise evaluation of the obtainable spatial resolution is needed. Finally, available data on the value of the loss factor for electron exchange during scattering ${ }^{4,5}$ are incorporated.

\section{EXPERIMENTAL CONSIDERATIONS}

The broadening $\sigma_{\theta}$ of the scattered spectrum by a beam divergence with standard deviation $s_{\theta}$ can be expressed as

$$
\frac{\sigma_{\theta}}{\sigma}=\frac{\sigma}{T_{i}} \frac{s_{\theta}}{\theta}
$$

A similar expression can be derived for the energy spread $s_{E}$ of the source:

$$
\frac{\sigma_{E}}{\sigma}=\frac{E_{0}}{\sigma} \frac{s_{E}}{E_{b}} .
$$

The combined effects of Eqs. (1), (5), and (6) on the energy spread $s$ of the measured spectrum is

$$
s^{2}=\sigma^{2}+\sigma_{E}^{2}+\sigma_{\theta}^{2}
$$

and the contribution of beam imperfections can therefore be corrected for.

The effect of the length $/$ of the scattering volume on the spatial resolution $\delta x$ is calculated for a temperature that depends linearly on the length coordinate $x$ within the volume. The center of the volume $(x=0)$ is denoted by index 0 . An error analysis up to second order in the perturbation of $T$ shows that $\sigma^{2}$ is changed to

$$
\overrightarrow{s^{2}} \cong \sigma_{0}^{2}\left[1+\frac{1}{3} l^{2}\left(T_{0}^{\prime} / T_{0}\right)^{2}\right] .
$$

Considering the assumed $T(x)$ dependence, the discrepancy between $\bar{s}^{2}$ and $\sigma_{0}^{2}$ can be translated into an uncertainty in the position:

$$
\delta x=\frac{1}{3} l^{2}\left(T_{0}^{\prime} / T_{0}\right) .
$$

Since $l T_{0}^{\prime} / T_{0}$ will be less than one, $\delta x$ remains smaller than one third of the length of the scattering volume. Poloidal alignment of the scattering volume will further improve the spatial resolution.

The temporal resolution is related via the number of counts $N$, to the accuracy in the ion temperature ${ }^{6}$ :

$$
\Delta T_{i} / T_{i}=\sqrt{2 /(N-1)}
$$




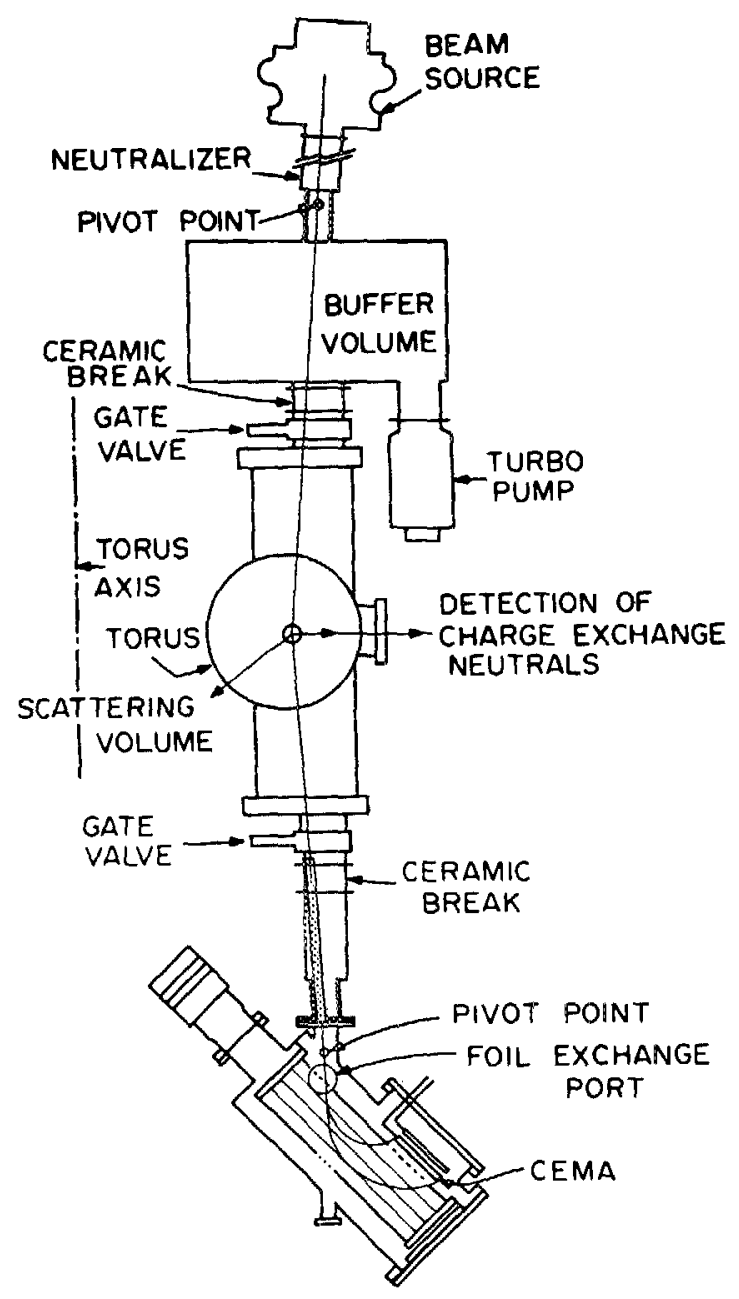

FIG. 1. Experimental arrangement.

\section{EXPERHMENTAL ARRANGEMENT}

Figure 1 shows the experimental arrangement. At 20 $\mathrm{keV}$, the source provides a current density of $36 \mathrm{~A} / \mathrm{m}^{2}$ for a $1-\mathrm{cm}$-wide He beam in the target area. The detector, of the electrostatic deflection type, contains a stripping foil and a linear channel plate with eight anodes each having an area of $1.8 \times 10^{-4} \mathrm{~m}^{2}$. Taking into account the detector efficiency, the loss factor due to electron exchange during scattering and the neutral flux attenuation by the plasma, a total count rate of $5.3 \times 10^{6} \mathrm{~s}^{-1}$ is expected for a $20-\mathrm{keV}$ He beam scattered at $8^{\circ}$ by the STOR-M tokamak plasma $\left(T_{i}=100 \mathrm{eV}, T_{e}=300 \mathrm{eV}, n_{i}=2 \times 10^{19} \mathrm{~m}^{-3}\right)$. For a similar hydrogen beam the count rate would be much less, i.e., $1.4 \times 10^{4} \mathrm{~s}^{-1}$. The count rate due to background neutrals originating from the incident beam after double charge exchange is $2.5 \times 10^{4} \mathrm{~s}^{-1}$ for helium and $2.7 \times 10^{6} \mathrm{~s}^{-1}$ for hydrogen in the case of a $20-\mathrm{keV}$ beam. It is clear that a helium beam must be chosen to obtain useful information on $T_{i}$.

The accuracy of the measurements, as calculated from the foregoing, is $10 \%$ in $T_{i}$ at a temporal resolution of $40 \mu \mathrm{s}$ and a radial resolution of $1 \mathrm{~cm}$ or less.

'V. G. Abramov, V. V. Afrosimov, I. P. Gladkovskii, A. I. Kislyakov, and V. I. Perel, Sov. Phys. Tech. Phys. 16, 1520 (1972).

${ }^{2}$ E. V. Aleksandrov, V. V. Afrosimov, E. L. Berezovskii, A. B. Izvozchikov, V. I. Marasev, A. I. Kislyakov, E. A. Mikhailov, M. L. Petrov, and G. V. Roslyakov., JETP Lett. 29, 1 (1979).

${ }^{3}$ E. L. Berezovskii, A. I. Kislyakov, S. Ya. Petrov, and G. V. Roslyakov, Sov. J. Plasma Phys. 6, 720 (1980).

${ }^{4}$ T. Donne, FOM Institute for Plasma Physics, Rijnhuizen (private communications, 1985).

${ }^{5}$ F. P. Ziemba, G. J. Lockwood, G. H. Morgan, and E. Everhart, Phys. Rev. $118,1552(1960)$.

${ }^{6}$ G. H. J. Notermans, H. W. van der Ven, and H. J. B. M. Brocken, Report RR-82-140, Rijnhuizen, 1982. 